\title{
Fungal spores overwhelm biogenic organic aerosols in a midlatitudinal forest
}

\author{
Chunmao Zhu ${ }^{1,2, a}$, Kimitaka Kawamura ${ }^{1, b}$, Yasuro Fukuda ${ }^{1,3}$, Michihiro Mochida ${ }^{4, c}$, and Yoko Iwamoto ${ }^{4, d}$ \\ ${ }^{1}$ Institute of Low Temperature Science, Hokkaido University, Sapporo 0600819, Japan \\ ${ }^{2}$ CMA Key Laboratory of Aerosol-Cloud-Precipitation, Nanjing University of Information Science and Technology, \\ Nanjing 210044, China \\ ${ }^{3}$ Graduate School of Environmental Science, Hokkaido University, Sapporo 0600810, Japan \\ ${ }^{4}$ Institute of Advanced Research, Nagoya University, Nagoya 4648601, Japan \\ a now at: Department of Environmental Geochemical Cycle Research, Japan Agency for Marine-Earth Science and \\ Technology, Yokohama 2360001, Japan \\ bnow at: Chubu Institute for Advanced Studies, Chubu University, Kasugai 4878501, Japan \\ ${ }^{\mathrm{c}}$ now at: Graduate School of Environmental Studies, Nagoya University, Nagoya 4648601, Japan \\ d now at: Faculty of Science Division I, Tokyo University of Science, Tokyo 1628601, Japan
}

Correspondence to: Kimitaka Kawamura (kkawamura@isc.chubu.ac.jp) and Chunmao Zhu (chmzhu@jamstec.go.jp)

Received: 27 August 2015 - Published in Atmos. Chem. Phys. Discuss.: 4 February 2016

Revised: 13 May 2016 - Accepted: 25 May 2016 - Published: 16 June 2016

\begin{abstract}
Both primary biological aerosol particles (PBAPs) and oxidation products of biogenic volatile organic compounds (BVOCs) contribute significantly to organic aerosols (OAs) in forested regions. However, little is known about their relative importance in diurnal timescales. Here, we report biomarkers of PBAP and secondary organic aerosols (SOAs) for their diurnal variability in a temperate coniferous forest in Wakayama, Japan. Tracers of fungal spores, trehalose, arabitol and mannitol, showed significantly higher levels in nighttime than daytime $(p<0.05)$, resulting from the nocturnal sporulation under near-saturated relative humidity. On the contrary, BVOC oxidation products showed higher levels in daytime than nighttime, indicating substantial photochemical SOA formation. Using tracer-based methods, we estimated that fungal spores account for $45 \%$ of organic carbon (OC) in nighttime and $22 \%$ in daytime, whereas BVOC oxidation products account for 15 and $19 \%$, respectively. To our knowledge, we present for the first time highly time-resolved results that fungal spores overwhelmed BVOC oxidation products in contributing to OA especially in nighttime. This study emphasizes the importance of both PBAPs and SOAs in forming forest organic aerosols.
\end{abstract}

\section{Introduction}

Biogenic particles and gases emitted from various vegetation types affect earth climate, biogeochemical cycles of carbon and nitrogen, air quality and human health. Particles such as fungal and fern spores, bacteria, viruses, algae, vegetation debris and pollen are directly emitted and thus termed as primary biological aerosol particles (PBAPs) (Després et al., 2012; Elbert et al., 2007). Being mostly in the size range of $0.1-100 \mu \mathrm{m}$, PBAPs often contribute to a large mass fraction of organic aerosols (OAs) but a small fraction of total particles (Pöschl et al., 2010). On the other hand, biogenic volatile organic compounds (BVOCs) are highly reactive and thus subjected to photooxidation to form fine particles of secondary organic aerosols (SOAs) and gas-particle partitioning of the reaction products (Claeys et al., 2004). There are substantial progresses in understanding the source strengths, composition and atmospheric transformations of biogenic particles, however, their contributions to OA and hence forces of their effects on climate are still uncertain.

Global PBAP emission is as high as $1000 \mathrm{Tg} \mathrm{yr}^{-1}$ (Jaenicke, 2005). Fungal spore is the dominant component with the emission strengths of $8-186 \mathrm{Tg} \mathrm{yr}^{-1}$ (Després et al., 2012; Elbert et al., 2007; Heald and Spracklen, 2009). Fungal spores $(1-30 \mu \mathrm{m})$ could account for up to $45 \%$ of coarse par- 
ticulate matter (Fröhlich-Nowoisky et al., 2009). In contrast, global bacteria emissions are much smaller with abundances of 0.04-1.8 $\mathrm{Tg} \mathrm{yr}^{-1}$ (Burrows et al., 2009). Pollen could contribute up to $65 \%$ of total PBAP mass in the flowering season, although their number contribution is only $\sim 1 \%$ of total PBAP (Manninen et al., 2014). Certain PBAPs showed close correlations with atmospheric cloud condensation nucleus (CCN) and ice nucleus (IN) (Hiranuma et al., 2015; Huffman et al., 2013). However, simulations indicated that PBAPs are of regional importance for IN formation as they contribute very little to global average ice nucleation rates (Hoose et al., 2010; Spracklen and Heald, 2014). Unveiling PBAP mass concentrations is necessary to provide benchmarks for simulating its nucleation potentials and the effect on the climate.

The most widely studied BVOCs are isoprene $\left(\mathrm{C}_{5} \mathrm{H}_{8}\right)$, monoterpenes $\left(\mathrm{C}_{10} \mathrm{H}_{16}\right)$ and sesquiterpenes $\left(\mathrm{C}_{15} \mathrm{H}_{24}\right)$. Global emission of isoprene (309-706 $\mathrm{Tg} \mathrm{C} \mathrm{yr}^{-1}$ ) accounts for $\sim 50 \%$ of total BVOC (Acosta Navarro et al., 2014; Guenther et al., 2006). Monoterpenes ( $\sim 10 \%$ of total VOCs) and sesquiterpenes are other important SOA precursors (Ziemann and Atkinson, 2012). Atmospheric oxidation of these BVOCs depends on oxidant levels $\left(\mathrm{NO}_{x}\right.$ and $\left.\mathrm{O}_{3}\right)$, humidity, light and temperature. Recent studies indicated that biogenic SOA production could be enhanced under the input of anthropogenic oxidants (Carlton et al., 2010). Under pristine conditions, BVOC oxidation and SOA formation are often accompanied by new particle formation, involving precipitation through increasing $\mathrm{CCN}$ and IN numbers (Pöschl et al., 2010). The formation of SOA is often in the fine particle size (Pöschl et al., 2010); however, the relative importance of PBAPs and SOA in contributing to OA is still ambiguous.

Various observational methods have been applied to explore PBAPs and SOA in natural environment both qualitatively and quantitatively. Applications of ultraviolet aerodynamic particle sizers and wideband integrated bioaerosol sensor based on fluorescence provided much information on the abundances and size distributions of PBAP (Huffman et al., 2010; Pöhlker et al., 2012). In situ observations of SOA are frequently conducted using an aerosol mass spectrometer (AMS) (Zhang et al., 2007). BVOC could also be monitored in real time using proton-transfer reaction mass spectrometry (PTR-MS) technology (Blake et al., 2009). Detections of organic tracer compounds using gas chromatography combined with mass spectrometry (GC/MS) make it possible to compare both PBAP and SOA sources simultaneously (Graham et al., 2003). Progress is achieved in boreal forest (Kourtchev et al., 2008) and the Amazon (Graham et al., 2003). However, few studies focused on the midlatitudinal forest with high time resolution (Miyazaki et al., 2012; Mochizuki et al., 2015).

In this study, we collected daytime and nighttime samples in a midlatitude forest in Wakayama, Japan and analyzed the organic samples for various PBAP and SOA tracers us- ing GC/MS. We report for the first time that fungal spores overwhelm BSOA in contributing to aerosol organic carbon (OC). We also report diurnal variations of PBAP tracers that reflect the natural rhythm of the forest.

\section{Experimental}

\subsection{Site and sampling}

Aerosol sampling was conducted 20-30 August 2010 during a field campaign at Wakayama Forest Research Station, Kyoto University, in the Kii Peninsula, Japan $\left(34.06^{\circ} \mathrm{N}\right.$, $135.52^{\circ} \mathrm{E}$, ca. $750 \mathrm{~m}$ a.s.1.) (Han et al., 2013, 2014). The dominant species of the forest vegetation are coniferous trees of Cryptomeria japonica (Japanese cedar), Chamaecyparis obtuse (Japanese cypress) and Pinus densiflora (Japanese red pine). Previous studies indicated that monoterpenes are abundantly emitted from these tree species (Matsunaga et al., 2011; Mochizuki et al., 2011). Total suspended particulate (TSP) samples were collected on precombusted $\left(450^{\circ} \mathrm{C}, 6 \mathrm{~h}\right)$ quartz filters (Pallflex 2500QAT-UP, $20 \mathrm{~cm} \times 25 \mathrm{~cm}$ ) using a high-volume air sampler (Kimoto AS-810B) at a flow rate of $\sim 60 \mathrm{~m}^{3} \mathrm{~h}^{-1}$ at the ground level. Each of the quartz samples were kept in a sealed glass jar at $<-20^{\circ} \mathrm{C}$ during transport. The quartz filters were then stored at $\sim-20^{\circ} \mathrm{C}$ in the laboratory prior to chemical analysis. We believe that the chemical losses were not large under the low temperature and sealed condition (Kawamura et al., 2010). During the campaign, four field blanks were collected following the sampling procedures, except for the running of pump for only $10 \mathrm{~s}$.

Nighttime (from $\sim$ 18:00 to $\sim 06: 00 \mathrm{LT}$ ) and daytime (from $\sim$ 06:00 to $\sim$ 18:00 LT) samples were collected separately each day. Of the whole sampling period, the backward trajectories were calculated using HYSPLIT dispersion model starting at every hour of the day and for different starting height $(500,1000$ and $1500 \mathrm{ma.g} .1$.) (Han et al., 2013, 2014). It can be seen that the air masses were mainly originated from the Asian continent or passed over the Japanese islands during 20-25 August, which were expected to deliver pollutants from anthropogenic sources. On the other hand, air masses were mainly originated from the western North Pacific during 26-30 August, which create an environment close to the pristine forest. On 23 and 28 August, samples were collected every $3 \mathrm{~h}$ (namely, 06:00-09:00, 09:00-12:00, 12:00-15:00, 15:0018:00, 18:00-21:00, 21:00-24:00, 24:00-3:00 and 03:0006:00 LT). A total of 36 samples were collected during the campaign.

\subsection{Chemical analysis}

For the determination of organic molecular tracers in aerosols, filter samples were first extracted with dichloromethane/methanol and derivatized by N,O-bis(trimethylsilyl)trifluoroacetamide (BSTFA) mixed with 


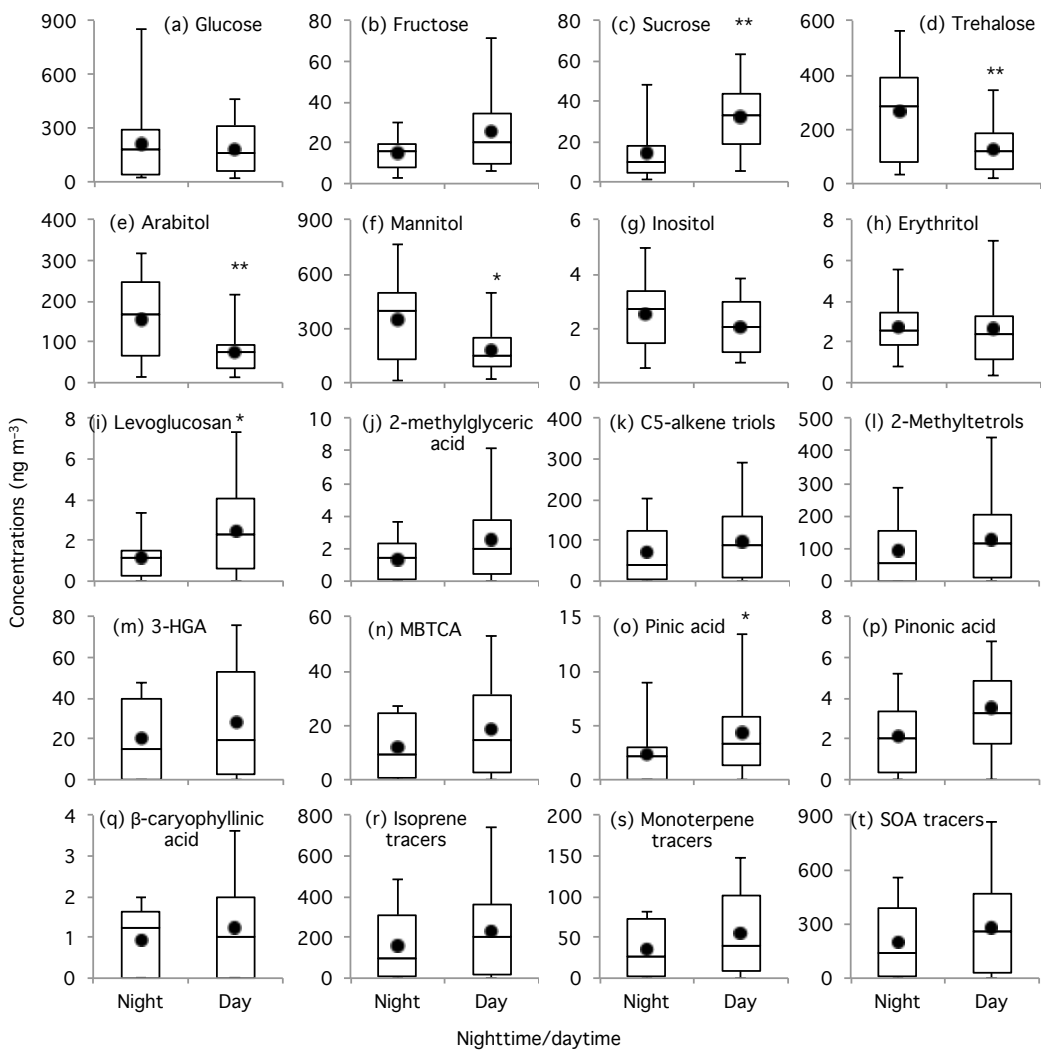

Figure 1. Diurnal variations of organic compounds in forest aerosols in Wakayama, Japan during 20-30 August 2010. The 10th, 25th, 50th, 75th and 90th percentiles of the nighttime and daytime samples were shown in the box-and-whisker plot. The means were shown in solid circles. Statistically significant values were also shown $\left(t\right.$ test, $\left.{ }^{*} p<0.05 ;{ }^{* *} p<0.01\right)$.

pyridine to convert $\mathrm{OH}$ groups to trimethylsilyl (TMS) ethers and $\mathrm{COOH}$ groups to TMS esters (Simoneit et al., 2004). The extracts were kept at $\sim-20^{\circ} \mathrm{C}$ and then organic compounds were quantified within $24 \mathrm{~h}$ by GC/MS using an Agilent 7890A GC equipped with HP-5ms capillary column $(30 \mathrm{~m} \times 0.25 \mathrm{~mm} \times 0.25 \mu \mathrm{m})$ coupled to Agilent $5975 \mathrm{C}$ mass selective detector (MSD). Individual compounds were identified by comparing the mass spectra with those of authentic standards or literature data and quantified by comparing the peak areas with the internal standard $\left(\mathrm{C}_{13}\right.$ n-alkane $)$ (Zhu et al., 2015b). Recoveries for the authentic standards or surrogates were generally better than $80 \%$, except for pinonic acid of $\sim 60 \%$, as obtained by spiking standards to precombusted quartz filters following extraction and derivatization. No peak was found for the target compounds in the field and laboratory blanks. The analytical errors by duplicate analyses were less than $15 \%$. The detection limits of the reported compounds were $105-557 \mathrm{pg} \mu \mathrm{L}^{-1}$, which correspond to ambient concentrations of $12-64 \mathrm{pg} \mathrm{m}^{-3}$ under a typical sampling volume of $700 \mathrm{~m}^{3}$ and usage of $10 \mathrm{~cm}^{2}$ filter section.

Aerosol OC was determined using a thermal/optical carbon analyzer (Sunset Laboratory Inc., USA) following the Interagency Monitoring Protected Visual Environments (IM-
PROVE) thermal evolution protocol (Birch and Cary, 1996). The analytical error in replicate analyses was within $8 \%$. Samples were corrected for field blanks, in which OC level was $<5 \%$ of the samples. Inorganic ions were measured using an ion chromatograph (761 Compact IC, Metrohm, Switzerland). $\mathrm{SO}_{4}^{2-}$ and $\mathrm{NO}_{3}^{-}$were discussed in the study. The detection limits were $\sim 0.1 \mathrm{ng} \mathrm{m}^{-3}$. The laboratory analytical error was within $5 \%$. Samples were corrected for field blanks.

Statistical significance of daytime and nighttime organic tracers was evaluated based on Student's $t$ test at $p<0.05$ and $p<0.01$ level, respectively. To explore the effects of anthropogenic pollutant inputs on BSOA formation, linear correlations (Pearson) between SOA tracers and $\mathrm{NO}_{3}^{-}$and $\mathrm{SO}_{4}^{2-}$ where investigated. The contributions from various sources to $\mathrm{OC}$ were estimated using tracer-based methods using conversion factors according to the preceding studies. 


\section{Results and discussion}

\subsection{PBAP tracers reflecting diurnal rhythm of fungal spores and pollen}

\subsubsection{Fungal spore tracers}

Four primary saccharides (trehalose, glucose, fructose and sucrose) and four sugar alcohols (arabitol, mannitol, inositol and erythritol) were detected in the forest aerosols as PBAP tracers. Trehalose, arabitol and mannitol were the major species of fungus and have been used as tracers for fungal spores (Jia and Fraser, 2011). These compounds showed significantly higher levels in nighttime $(262 \pm 168,156 \pm 102$ and $349 \pm 243 \mathrm{ng} \mathrm{m}^{-3}$ for trehalose, arabitol and mannitol, respectively) than in daytime $(128 \pm 90.2,76.0 \pm 54.9$ and $183 \pm 139 \mathrm{ng} \mathrm{m}^{-3}$, respectively) ( $t$ test, $p<0.05$, Fig. $1 \mathrm{~d}-\mathrm{f}$ ). High abundances of these fungal spore tracers were resulting from the nocturnal sporulation under near saturated relative humidity (Fig. 2). In nighttime, the mean relative humidity was $96 \%$ in the sampling period. Nevertheless, the mean daytime relative humidity was still as high as $88 \%$. Such a moist environment caused enrichment of fungal spores and their discharges, resulting high abundances of their tracer in aerosols. The sum of trehalose, arabitol and mannitol contributed to $70 \%$ of total PBAP tracer mass, demonstrating an important role of fungi in regulating the land-atmosphere exchange in the forest region.

Diurnal profiles of fungal spore tracers showed similar pattern on 23 and 28 August, two typical days representing regional and local phenomenon, respectively. Minima of trehalose, arabitol and mannitol appeared around noon and increased dramatically in the evening on both days (Fig. 3). On 23 August, fungal spore tracers peaked at 21:00-24:00 LT and decreased slowly thereafter. In comparison, these compounds peaked slightly earlier at 18:00-21:00 LT on $28 \mathrm{Au}-$ gust. The maxima of these compounds on 23 August were higher by a factor of $\sim 1.5$ than those on 28 August. This phenomenon was likely related to the precipitation that occurred at 13:00-17:00 LT, 23 August (Fig. 2), which favors the growth and release of fungal spores.

\subsubsection{Other PBAP tracers and levoglucosan}

Sucrose, a key component of pollen grain (Yttri et al., 2007), showed significantly higher levels $(p<0.01)$ in daytime $\left(31.9 \pm 17.7 \mathrm{ng} \mathrm{m}^{-3}\right)$ than nighttime $\left(14.6 \pm 14.2 \mathrm{ng} \mathrm{m}^{-3}\right)$ (Fig. 1c). The diurnal profile of sucrose showed peaks in the afternoon (Fig. 3a), indicating the flowering time of the vegetation. As the blossom season of the dominant coniferous trees is March-April in the region, the source of sucrose is likely from the pollen of the widely distributed floor vegetation, Ambrosia artemisiifolia, Artemisia indica and plants of Poaceae family, which are flowering during the sampling period.

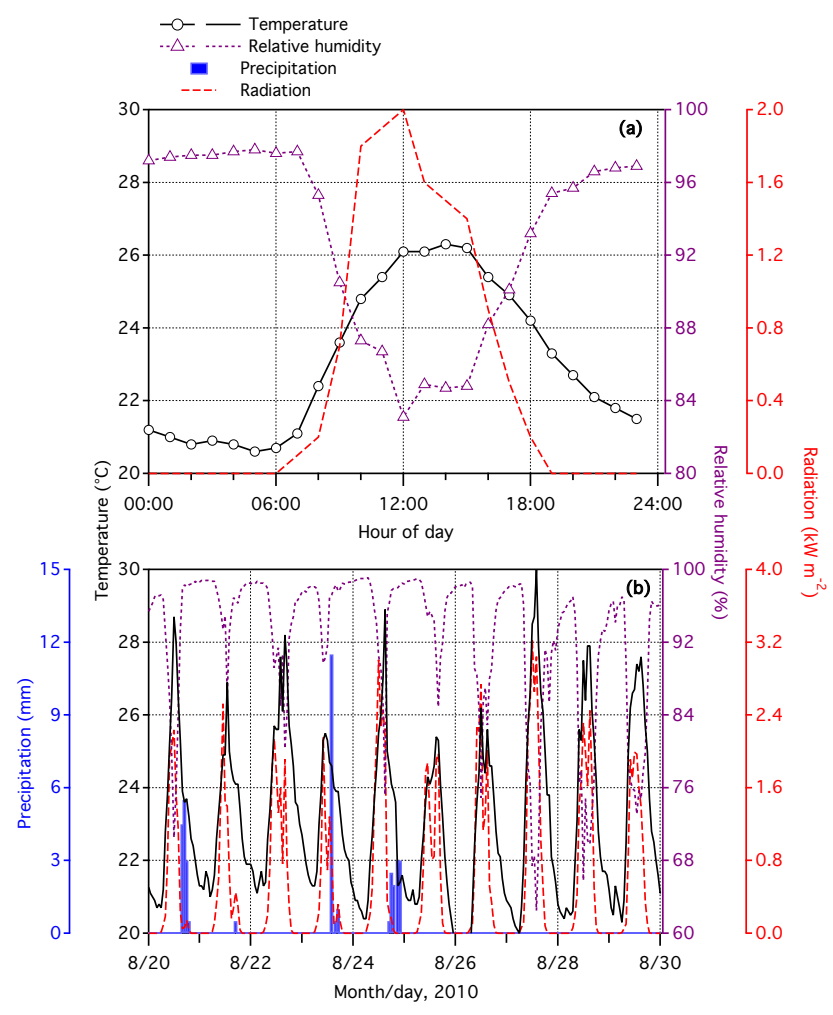

Figure 2. Meteorological parameters during 20-30 August 2010 in the Wakayama forest for (a) averaged diurnal variations of temperature, relative humidity and solar radiation and (b) hourly means over the periods. Hourly precipitation was also shown in (b).

Glucose and fructose are dominantly originated from plant debris (Medeiros et al., 2006; Zhu et al., 2015a) and sometimes from microorganisms and soil dust (Rogge et al., 2007; Simoneit et al., 2004). There was no serious continental outflow of Asian dust over the sampling period (based on observations by Japan Meteorological Agency). Insignificant diurnal variations of these two compounds imply that they were emitted both in the daytime and the nighttime in the forest possibly from plants and microorganisms (Figs. 1a$b, 3 a)$. The diurnal variation of planetary boundary layer height could also contribute to the observed variations of glucose and fructose and other PBAP tracers. In the daytime, enhanced vertical mixing might cause dilution effect to the observed PBAP tracers. While in the nighttime, the low wind speed favors the buildup of PBAP tracers in the canopy (Fig. S1 in the Supplement), resulting in the elevated levels (Fig. 3a, b). Interestingly, the mass concentrations of glucose were 1 order of magnitude higher than those of fructose. This might be related to the higher abundance of glucose in trees. For example, tissues of a wide range of subtropical plants were found to contain more glucose than fructose (Baker et al., 1998).

Being exclusively produced by the thermal depolymerization and dehydration of cellulose and hemicellu- 


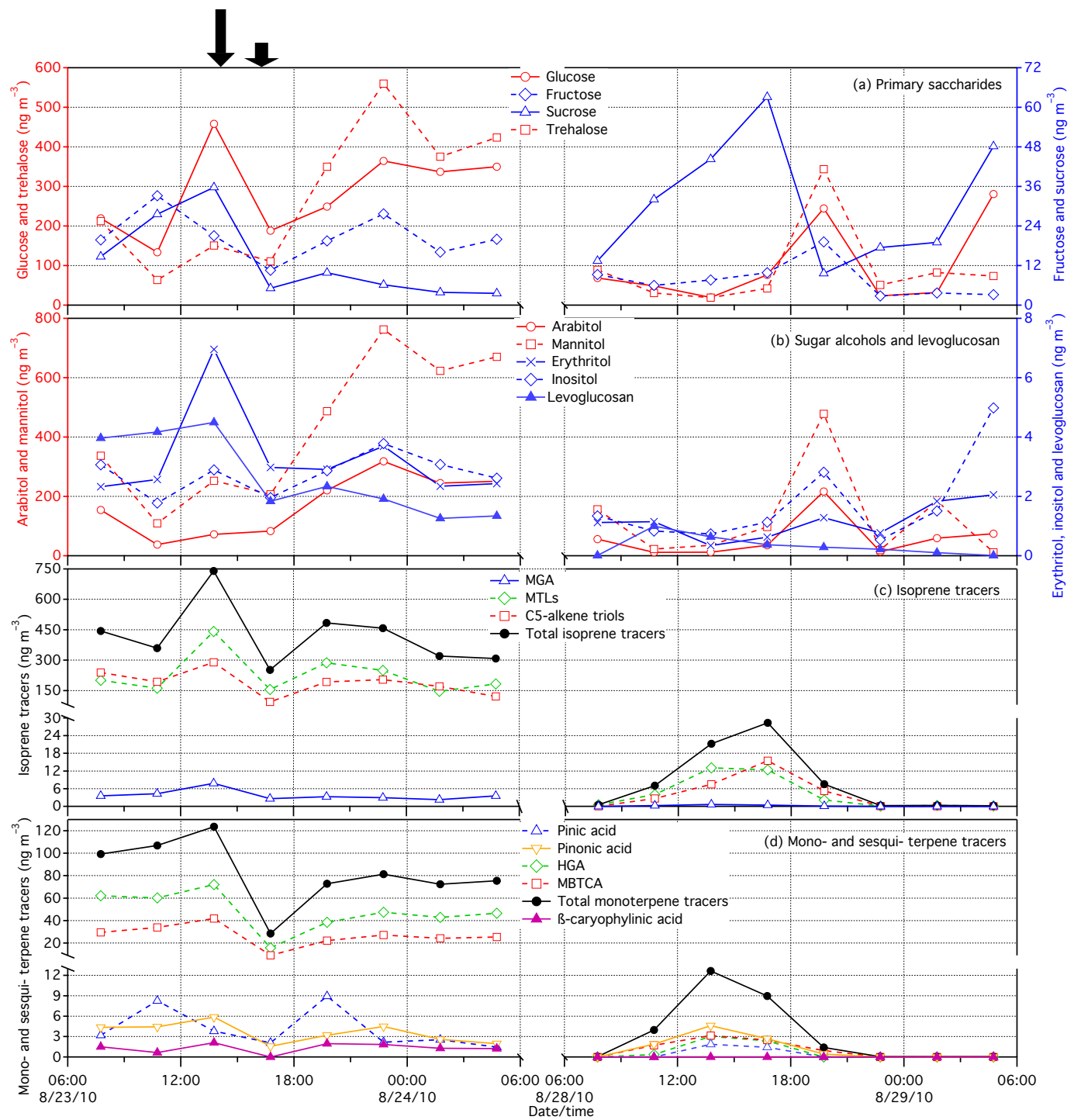

Figure 3. Diurnal profiles of organic compounds in forest aerosols in Wakayama on 23-24 August (left) and 28-29 August 2010 (right).

lose, levoglucosan has been used as a specific tracer for biomass burning (Simoneit et al., 1999; Zhu et al., 2015b). Levoglucosan showed significantly higher levels $(p<0.05)$ in daytime $\left(2.52 \pm 2.08 \mathrm{ng} \mathrm{m}^{-3}\right)$ than nighttime $\left(1.14 \pm 0.94 \mathrm{ng} \mathrm{m}^{-3}\right)$. Moreover, we found higher levels of levoglucosan 20-25 August $\left(2.97 \pm 1.64 \mathrm{ng} \mathrm{m}^{-3}\right)$ than $26-$ 30 August $\left(0.53 \pm 0.44 \mathrm{ng} \mathrm{m}^{-3}\right)$; those concentrations in the latter period are close to the regional background level from Okinawa Island (Zhu et al., 2015b). In the nighttime, levoglucosan may have been deposited to the canopy as a result of dampened vertical mixing and relatively low wind speed (Fig. S1). In addition, local burning activities could also contribute to the daytime elevation of levoglucosan although they might be insignificant.

\subsubsection{Daytime abundances of SOA tracers}

A total of 11 compounds were detected as SOA tracers. Six isoprene tracers, including 2-methylglyceric acid (MGA), two 2-methyl tetrols (2-methylthreitol and 2-methylerythritol, MTLs) and three C5-alkene triols (3-methyl-2,3,4-trihydroxy-1-butene, cis-2-methyl-1,3,4trihydroxy-1-butene and trans-2-methyl-1,3,4-trihydroxy-1butene, MTHBs), showed higher levels in daytime (Fig. 1j1). Similar daytime abundances were also found for four monoterpene tracers: pinonic acid (PNA), pinic acid (PA) $(p<0.05)$, 3-hydroxyglutaric acid (HGA) and 3-methyl1,2,3-butanetricarboxylic acid (MBTCA) (Fig. 1m-p). Total isoprene-SOA tracers $\left(281 \pm 274\right.$ and $199 \pm 207 \mathrm{ng} \mathrm{m}^{-3}$ in daytime and nighttime, respectively) were more abundant by a factor of $\sim 5$ than total monoterpene-SOA tracers 
Table 1. Linear correlation coefficients $(r)$ between secondary organic aerosol tracers and $\mathrm{NO}_{3}^{-}$and $\mathrm{SO}_{4}^{2-}$ in forest aerosols during $20-$ 30 August 2010, Wakayama, central Japan.

\begin{tabular}{llrrrrrrrrr}
\hline & & MGA $^{\mathrm{a}}$ & C5T & MTLs & $\begin{array}{r}\text { Isoprene } \\
\text { tracers }\end{array}$ & 3-HGA & MBTCA & PA & $\begin{array}{r}\text { PNA } \\
\text { Monoterpene } \\
\text { tracers }\end{array}$ \\
\hline $\mathrm{NO}_{3}^{-}$ & All data set & 0.08 & $-0.13^{\mathrm{b}}$ & -0.06 & -0.09 & -0.11 & -0.01 & -0.02 & 0.18 & -0.06 \\
& Daytime & -0.07 & -0.26 & -0.15 & -0.2 & -0.27 & -0.22 & -0.25 & 0.01 & -0.25 \\
& Nighttime & -0.32 & -0.36 & -0.34 & -0.35 & -0.30 & -0.18 & -0.33 & -0.19 & -0.27 \\
\hline $\mathrm{SO}_{4}^{2-}$ & All data set & $0.84^{\mathrm{e}}$ & $0.87^{\mathrm{e}}$ & $0.84^{\mathrm{e}}$ & $0.86^{\mathrm{e}}$ & $0.91^{\mathrm{e}}$ & $0.9^{\mathrm{e}}$ & $0.70^{\mathrm{e}}$ & $0.65^{\mathrm{e}}$ & $0.91^{\mathrm{e}}$ \\
& Daytime & $0.86^{\mathrm{e}}$ & $0.89^{\mathrm{e}}$ & $0.84^{\mathrm{e}}$ & $0.88^{\mathrm{e}}$ & $0.91^{\mathrm{e}}$ & $0.92^{\mathrm{e}}$ & $0.76^{\mathrm{e}}$ & $0.67^{\mathrm{d}}$ & $0.92^{\mathrm{e}}$ \\
& Nighttime & $0.82^{\mathrm{e}}$ & $0.82^{\mathrm{e}}$ & $0.82^{\mathrm{e}}$ & $0.83^{\mathrm{e}}$ & $0.90^{\mathrm{e}}$ & $0.86^{\mathrm{e}}$ & $0.53^{\mathrm{c}}$ & $0.58^{\mathrm{c}}$ & $0.89^{\mathrm{e}}$ \\
\hline
\end{tabular}

a Secondary organic aerosol tracer compounds are as follows: MGA, 2-methylglyceric acid; C5T, C5-alkene triols; MTLs, 2-methyl tetrols; PA, pinic acid; PNA, pinonic acid; 3-HGA, 3-hydroxyglutaric acid, MBTCA, 3-methyl-1, 2, 3-butanetricarboxylic acid. ${ }^{\mathrm{b}}$ Negative values indicate negative correlations. ${ }^{\mathrm{c}} p<0.05$; ${ }^{\mathrm{d}} p<0.01 ;{ }^{\mathrm{e}} p<0.001$.

(54.6 \pm 50.2 and $36.3 \pm 33.6 \mathrm{ng} \mathrm{m}^{-3}$, respectively). Isoprene is more abundantly emitted than monoterpenes from this coniferous forest. This is consistent with the observations at a mountain site in central Japan (Fu et al., 2014). Sesquiterpene tracer, caryophyllinic acid, showed consistently low levels in both daytime $\left(1.22 \pm 1.23 \mathrm{ng} \mathrm{m}^{-3}\right)$ and nighttime $\left(0.94 \pm 0.83 \mathrm{ng} \mathrm{m}^{-3}\right)$ (Fig. 1q). The daytime abundances of isoprene and monoterpene tracers reflected the production of SOA by the photooxidation of BVOC in the forest.

\subsection{Influence of anthropogenic oxidant on SOA formation}

The diurnal profile of SOA tracers showed a clear singlepeak pattern in the afternoon on 28-29 August. Total isoprene tracers peaked at 15:00-18:00 LT $\left(28.4 \mathrm{ng} \mathrm{m}^{-3}\right)$, while total monoterpene tracers peaked slightly earlier at 12:0015:00 LT (12.7 $\mathrm{ng} \mathrm{m}^{-3}$ ) (Fig. 3c-d). Their afternoon peaks are consistent with the maxima of ambient temperature and solar radiation (Fig. 2). These results indicate that SOA is formed by photooxidation of isoprene and monoterpenes emitted from local vegetation under natural conditions. Our results are consistent with the afternoon peaks of semivolatile oxygenated organic aerosol (SVOOA) component determined by the positive matrix factorization of the AMS spectra collected during the same campaign (Han et al., 2014), which were produced by photooxidation of freshly emitted BVOCs from the local forest.

Interestingly, on 23-24 August, days with regional anthropogenic oxidant input, isoprene and monoterpene tracers showed not only afternoon peaks at 12:00-15:00 LT but also nighttime peaks (Fig. 3c-d) following the intensive precipitation during 13:00-17:00 LT (Fig. 2). These results suggest that SOA is continuously produced even in nighttime with sufficient oxidants. AMS observation in the same campaign indicated that highly oxidized low volatility oxygenated organic aerosols (LVOOA) are even more abundant than that of SVOOA on 23-24 August, especially in nighttime (Han et al., 2014). Nighttime production of SOA was also observed in the United States (Zhao et al., 2013).

Moreover, on days with regional input of oxidants, the SOA tracer levels were 1-2 orders of magnitude higher than those under natural conditions both in daytime and nighttime. Meanwhile, we found positive relations between $\mathrm{SO}_{4}^{2-}$ and isoprene-SOA tracers as well as monoterpene-SOA tracers (Table 1). These phenomena could be explained by the following reasons. Firstly, regional BSOA could be transported along with anthropogenic oxidants. Observations at Okinawa Island, southern Japan indicated that the variations of monoterpene-SOA tracers and caryophyllinic acid are related to the continental outflow of BVOC oxidation products (Zhu et al., 2016). Secondly, the earlier-generation products of BVOC oxidation tend to shift to the particle phase during gas-particle partitioning given their semivolatile nature (Cahill et al., 2006), such a shift might be more prominent on days with aged regional aerosols accompanied by a daytime increase of organics determined by AMS (Han et al., 2014). The third possibility is that the anthropogenic oxidants might promote BSOA formation. We focused on the third possibility and further testified this hypothesis.

We examined the degrees of BSOA tracer buildups in daytime as compared to nighttime ( $\triangle \mathrm{BSOA}$ represents the mathematical difference between the daytime BSOA tracer level and the nighttime BSOA tracer level) (Table 2). $\triangle \mathrm{BSOA}$ values during 20-25 August were higher by more than 1 order of magnitude than during 26-30 August. These results implied that, although transported BSOA might contribute to their elevation, anthropogenic oxidants substantially promoted the SOA formation in the Wakayama forest. A recent field study in the southeastern US suggested that the formation of methyl tetrols is mediated by $\mathrm{SO}_{4}^{2-}$, being consistent with our results (Xu et al., 2015). They also reported that $\mathrm{NO}_{3}^{\circ}$ radical was involved in the nighttime monoterpene oxidation. However, inorganic $\mathrm{NO}_{3}^{-}$did not correlate with monoterpene-SOA tracers during nighttime, indicating that the contribution of $\mathrm{NO}_{3}^{\circ \mathrm{g}}$ radical to nighttime monoterpene 
Table 2. Daytime buildups (differences between daytime and nighttime levels) of SOA tracers on days with (20-25 August) and without (26-30 August) input of anthropogenic oxidants in forest aerosols, Wakayama, central Japan.

\begin{tabular}{lrrrrrrrrrrr}
\hline Period & MGA* & C5T & MTLs & $\begin{array}{r}\text { Isoprene } \\
\text { tracers }\end{array}$ & 3-HGA & MBTCA & PA & PNA & $\begin{array}{r}\text { Monoterpene } \\
\text { tracers }\end{array}$ & CPA & $\begin{array}{r}\text { BSOA } \\
\text { tracers }\end{array}$ \\
\hline 20-25 August & 2.06 & 47.1 & 60.9 & 110 & 14.1 & 12.0 & 3.31 & 1.52 & 30.9 & 0.10 & 141 \\
26-30 August & 0.02 & 1.73 & 2.33 & 4.08 & 0.16 & 0.22 & 0.37 & 1.18 & 1.93 & 0.51 & 6.53 \\
20-30 August & 1.17 & 27.2 & 35.3 & 63.7 & 7.98 & 6.87 & 2.03 & 1.37 & 18.2 & 0.28 & 82.2 \\
\hline
\end{tabular}

* Secondary organic aerosol tracer compounds are as follows: MGA, 2-methylglyceric acid; C5T, C5-alkene triols; MTLs, 2-methyl tetrols; PA, pinic acid; PNA, pinonic acid; 3-HGA, 3-hydroxyglutaric acid, MBTCA, 3-methyl-1, 2, 3-butanetricarboxylic acid; CPA, $\beta$-caryophyllinic acid; BSOA tracers are the sum of isoprene, monoterpene and sesquiterpene (CPA) tracers.

oxidation is not clear in Wakayama aerosols, which deserve further investigation.

\subsection{OC fractions from fungal spores and BVOC oxidation}

The contributions of each source component to $\mathrm{OC}$ were estimated using tracer-based methods. OC fractions from fungal spores were estimated based on mannitol levels assuming that there were $1.7 \mathrm{pg}$ mannitol and $13 \mathrm{pg}$ OC per spore (Bauer et al., 2008). The secondary organic carbon (SOC) fraction resulting from VOC oxidation was estimated following Kleindienst et al. (2007) based on the chamber experiment. Contributions of plant debris to OC were estimated based on glucose following Puxbaum and TenzeKunit (2003). Contributions of biomass burning aerosols to OC were estimated based on levoglucosan following Zhu et al. (2015b). It is noteworthy that, although each tracer method gave a reasonable estimate in the original studies, uncertainties would be introduced in the current study considering the site differences. Still, the estimations are inferable for the contributions from each source to $\mathrm{OC}$ in the forest aerosols.

Fungal spores contribute a major fraction ( $45 \%)$ to OC in nighttime. In daytime, although the mass fraction was about half of that in nighttime (22\%), fungal spores are still the largest known source of OC (Fig. 4). In comparison, BVOC oxidation products (BSOC) contribute to 15 and $19 \%$ of OC in nighttime and daytime, respectively. Interestingly, the large BSOC fraction of OC mainly occurred on days with anthropogenic influences (20-25 August) (17\% in daytime and $23 \%$ in nighttime). On days close to natural conditions (2629 August), BSOC has a small contribution to OC (4.0\% in nighttime and $4.7 \%$ in daytime). The larger contributions of BSOC to OC might be associated with the BSOC that are transported from the Asian continent, a stimulating effect of anthropogenic oxidants on daytime BSOA formation, as well as the enhanced gas to particle conversion of BVOC. These results suggest that increased fossil fuel combustion and the subsequent oxidant emissions would cause a larger contribution of BSOA to OA, which may in part compensate the human-caused global warming by acting as CCN. Such ef-

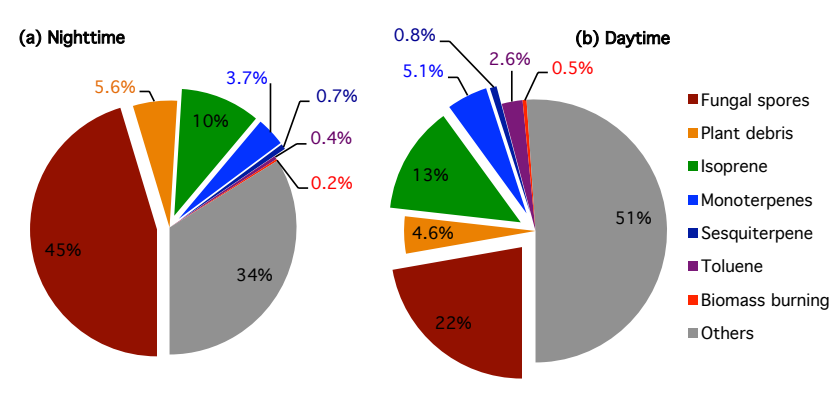

Figure 4. Contributions from different sources to organic carbon in the Wakayama forest aerosols during the nighttime and the daytime.

fects are supposed to be incorporated into model simulations of the future climate in the Anthropocene.

It is noteworthy that the contribution of plant debris to OC (5.6\% in nighttime and $4.6 \%$ in daytime) could not be neglected. These fractions account for only the primary OC sources based on glucose level, and could be underestimated. Nevertheless, there are still quite large amounts of OC not being determined (34 and $51 \%$ in nighttime and daytime, respectively). Other than the uncertainties introduced by the tracer methods, a notable fraction of OC could be contributed from humic-like substances that are chemically and physically similar with terrestrial and aquatic humic and fulvic acids (Graber and Rudich, 2006). Mono- and di-carboxylic acids, originating from a broad range of primary organic compounds, could contribute $38-44 \%$ of OC (Legrand et al., 2013). Pollen could also contribute to OC because of its large size. Amines are another source of OC, but not well studied (Sintermann and Neftel, 2015). These sources from various sectors need to be further characterized for an unambiguous understanding of the sources of forest aerosols.

Among few studies on the observation-based quantification of OC/OA sources of forest aerosols, our results are in accordance with those in the Amazon rainforest, where primary biological aerosol and SOA accounted for 68.5 and $18.8 \%$ of total particle masses, without consideration of the diurnal variations (Pöschl et al., 2010). At an urban site with various OA sources (Bakersfield, California), Zhao et al. (2013) reported that SOA accounted for 78 and $66 \%$ of OA during the daytime and the nighttime, respectively, while 
primary sources accounted for $15 \%$ of OA. Under a changing climate and uncertain anthropogenic emission scenario, although OA could be contributed by complicated sources in a pristine forest environment, our results demonstrate that biogenic particles and gases are rather the major sources of organic aerosols in the forest atmosphere.

\section{Conclusions}

We collected daytime and nighttime samples in a midlatitude coniferous forest in Wakayama, central Japan. Focusing on fungal spores and BSOA, we quantified organic tracers containing information of various aerosol sources. Nighttime higher levels of trehalose and sugar alcohols were clarified under near saturated relative humidity, indicating the flourishing of fungal sporulation. BSOA tracers were more abundant in the daytime, indicating their photooxidation production among other sources. Enhanced BSOA tracer levels were observed on days with notable input of anthropogenic oxidant. Using tracer-based methods, we estimated that fungal spores contribute dominantly to OC in forest aerosols not only in the nighttime but also in the daytime. The study emphasizes the importance of fungal spores in affecting biogenic aerosols in forest ecosystem.

\section{Data availability}

The data of this study is available upon request to C. Zhu.

\section{The Supplement related to this article is available online at doi:10.5194/acp-16-7497-2016-supplement.}

Acknowledgements. This study was supported in part by the Japan Society for the Promotion of Science (grant nos. 19204055 and 24221001), the Environment Research and Technology Development Fund (B-0903) from the Ministry of the Environment, Japan, and the Program for Improvement of Research Environment for Young Researchers from Special Coordination Funds for Promoting Science and Technology commissioned by Ministry of Education, Culture, Sports, Science and Technology, Japan. The authors thank the faculty and staff of Wakayama Forest Research Station (WFRS), Field Science Education and Research Center of Kyoto University, Japan, for the use of the site for aerosol sampling. The authors also thank Y. Han for her contribution to the aerosol sampling, and Y. Han and K. Kawana for their cooperation in the field observation. The meteorological data were provided by WFRS. The authors appreciate the experimental support of P. Fu and technical support of W. Zhang.

Edited by: S. M. Noe

\section{References}

Acosta Navarro, J. C., Smolander, S., Struthers, H., Zorita, E., Ekman, A. M., Kaplan, J., Guenther, A., Arneth, A., and Riipinen, I.: Global emissions of terpenoid VOCs from terrestrial vegetation in the last millennium, J. Geophys. Res., 119, 6867-6885, 2014.

Baker, H. G., Baker, I., and Hodges, S. A.: Sugar composition of nectars and fruits consumed by birds and bats in the tropics and subtropics1, Biotropica, 30, 559-586, 1998.

Bauer, H., Claeys, M., Vermeylen, R., Schueller, E., Weinke, G., Berger, A., and Puxbaum, H.: Arabitol and mannitol as tracers for the quantification of airborne fungal spores, Atmos. Environ., 42, 588-593, 2008.

Birch, M. and Cary, R.: Elemental carbon-based method for monitoring occupational exposures to particulate diesel exhaust, Aerosol. Sci. Tech., 25, 221-241, 1996.

Blake, R. S., Monks, P. S., and Ellis, A. M.: Proton-transfer reaction mass spectrometry, Chem. Rev., 109, 861-896, 2009.

Burrows, S. M., Elbert, W., Lawrence, M. G., and Pöschl, U.: Bacteria in the global atmosphere - Part 1: Review and synthesis of literature data for different ecosystems, Atmos. Chem. Phys., 9, 9263-9280, doi:10.5194/acp-9-9263-2009, 2009.

Cahill, T. M., Seaman, V. Y., Charles, M. J., Holzinger, R., and Goldstein, A. H.: Secondary organic aerosols formed from oxidation of biogenic volatile organic compounds in the Sierra Nevada Mountains of California, J. Geophys. Res., 111, D16312, doi:10.1029/2006JD007178, 2006.

Carlton, A. G., Pinder, R. W., Bhave, P. V., and Pouliot, G. A.: To what extent can biogenic SOA be controlled?, Environ. Sci. Technol., 44, 3376-3380, 2010.

Claeys, M., Graham, B., Vas, G., Wang, W., Vermeylen, R., Pashynska, V., Cafmeyer, J., Guyon, P., Andreae, M. O., Artaxo, P., and Maenhaut, W.: Formation of secondary organic aerosols through photooxidation of isoprene, Science, 303, 1173-1176, 2004.

Després, V. R., Huffman, J. A., Burrows, S. M., Hoose, C., Safatov, A. S., Buryak, G., Fröhlich-Nowoisky, J., Elbert, W., Andreae, M. O., Pöschl, U., and Jaenicke, R.: Primary biological aerosol particles in the atmosphere: a review, Tellus B, 64, 15598, doi:10.3402/tellusb.v64i0.15598, 2012.

Elbert, W., Taylor, P. E., Andreae, M. O., and Pöschl, U.: Contribution of fungi to primary biogenic aerosols in the atmosphere: wet and dry discharged spores, carbohydrates, and inorganic ions, Atmos. Chem. Phys., 7, 4569-4588, doi:10.5194/acp-7-4569-2007, 2007.

Fröhlich-Nowoisky, J., Pickersgill, D. A., Després, V. R., and Pöschl, U.: High diversity of fungi in air particulate matter, P. Natl. Acad. Sci. USA, 106, 12814-12819, 2009.

Fu, P., Kawamura, K., Chen, J., and Miyazaki, Y.: Secondary production of organic aerosols from biogenic VOCs over Mt. Fuji, Japan, Environ. Sci. Technol., 48, 8491-8497, 2014.

Graber, E. R. and Rudich, Y.: Atmospheric HULIS: How humic-like are they? A comprehensive and critical review, Atmos. Chem. Phys., 6, 729-753, doi:10.5194/acp-6-729-2006, 2006.

Graham, B., Guyon, P., Taylor, P. E., Artaxo, P., Maenhaut, W., Glovsky, M. M., Flagan, R. C., and Andreae, M. O.: Organic compounds present in the natural Amazonian aerosol: Characterization by gas chromatography-mass spectrometry, J. Geophys. Res., 108, 4766, doi:10.1029/2003JD003990, 2003. 
Guenther, A., Karl, T., Harley, P., Wiedinmyer, C., Palmer, P. I., and Geron, C.: Estimates of global terrestrial isoprene emissions using MEGAN (Model of Emissions of Gases and Aerosols from Nature), Atmos. Chem. Phys., 6, 3181-3210, doi:10.5194/acp-63181-2006, 2006.

Han, Y., Iwamoto, Y., Nakayama, T., Kawamura, K., Hussein, T., and Mochida, M.: Observation of new particle formation over a mid-latitude forest facing the North Pacific, Atmos. Environ., 64, 77-84, 2013.

Han, Y., Iwamoto, Y., Nakayama, T., Kawamura, K., and Mochida, M.: Formation and evolution of biogenic secondary organic aerosol over a forest site in Japan, J. Geophys. Res., 119, 259273, 2014

Heald, C. L. and Spracklen, D. V.: Atmospheric budget of primary biological aerosol particles from fungal spores, Geophys. Res. Lett., 36, L09806, doi:10.1029/2009GL037493, 2009.

Hiranuma, N., Möhler, O., Yamashita, K., Tajiri, T., Saito, A., Kiselev, A., Hoffmann, N., Hoose, C., Jantsch, E., and Koop, T.: Ice nucleation by cellulose and its potential contribution to ice formation in clouds, Nat. Geosci., 8, 273-277, 2015.

Hoose, C., Kristjánsson, J., and Burrows, S.: How important is biological ice nucleation in clouds on a global scale?, Environ. Res. Lett., 5, 024009, doi:10.1088/1748-9326/5/2/024009, 2010.

Huffman, J. A., Treutlein, B., and Pöschl, U.: Fluorescent biological aerosol particle concentrations and size distributions measured with an Ultraviolet Aerodynamic Particle Sizer (UVAPS) in Central Europe, Atmos. Chem. Phys., 10, 3215-3233, doi:10.5194/acp-10-3215-2010, 2010.

Huffman, J. A., Prenni, A. J., DeMott, P. J., Pöhlker, C., Mason, R. H., Robinson, N. H., Fröhlich-Nowoisky, J., Tobo, Y., Després, V. R., Garcia, E., Gochis, D. J., Harris, E., Müller-Germann, I., Ruzene, C., Schmer, B., Sinha, B., Day, D. A., Andreae, M. O., Jimenez, J. L., Gallagher, M., Kreidenweis, S. M., Bertram, A. K., and Pöschl, U.: High concentrations of biological aerosol particles and ice nuclei during and after rain, Atmos. Chem. Phys., 13, 6151-6164, doi:10.5194/acp-13-6151-2013, 2013.

Jaenicke, R.: Abundance of cellular material and proteins in the atmosphere, Science, 308, 73, doi:10.1126/science.1106335, 2005.

Jia, Y. and Fraser, M.: Characterization of saccharides in sizefractionated ambient particulate matter and aerosol sources: the contribution of primary biological aerosol particles (PBAPs) and soil to ambient particulate matter, Environ. Sci. Technol., 45, 930-936, 2011.

Kawamura, K., Kasukabe, H., and Barrie, L. A.: Secondary formation of water-soluble organic acids and $\alpha$-dicarbonyls and their contributions to total carbon and water-soluble organic carbon: Photochemical aging of organic aerosols in the Arctic spring, J. Geophys. Res., 115, D21306, doi:10.1029/2010JD014299, 2010.

Kleindienst, T. E., Jaoui, M., Lewandowski, M., Offenberg, J. H., Lewis, C. W., Bhave, P. V., and Edney, E. O.: Estimates of the contributions of biogenic and anthropogenic hydrocarbons to secondary organic aerosol at a southeastern US location, Atmos. Environ., 41, 8288-8300, 2007.

Kourtchev, I., Ruuskanen, T., Keronen, P., Sogacheva, L., Dal Maso, M., Reissell, A., Chi, X., Vermeylen, R., Kulmala, M., and Maenhaut, W.: Determination of isoprene and $\alpha-/ \beta$-pinene oxidation products in boreal forest aerosols from Hyytiälä, Finland: diel variations and possible link with particle formation events, Plant Bio., 10, 138-149, 2008.
Legrand, M., Preunkert, S., May, B., Guilhermet, J., Hoffman, H., and Wagenbach, D.: Major 20th century changes of the content and chemical speciation of organic carbon archived in Alpine ice cores: Implications for the long-term change of organic aerosol over Europe, J. Geophys. Res., 118, 3879-3890, 2013.

Manninen, H. E., Bäck, J., Sihto-Nissilä, S.-L., Huffman, J. A., Pessi, A.-M., Hiltunen, V., Aalto, P. P., Hidalgo Fernández, P. J., Hari, P., and Saarto, A.: Patterns in airborne pollen and other primary biological aerosol particles (PBAP), and their contribution to aerosol mass and number in a boreal forest, Boreal Environ. Res., 19, 383-405, 2014.

Matsunaga, S. N., Mochizuki, T., Ohno, T., Endo, Y., Kusumoto, D., and Tani, A.: Monoterpene and sesquiterpene emissions from Sugi (Cryptomeria japonica) based on a branch enclosure measurements, Atmos. Pollut. Res., 2, 2011.

Medeiros, P. M., Conte, M. H., Weber, J. C., and Simoneit, B. R.: Sugars as source indicators of biogenic organic carbon in aerosols collected above the Howland Experimental Forest, Maine, Atmos. Environ., 40, 1694-1705, 2006.

Miyazaki, Y., Jung, J., Fu, P., Mizoguchi, Y., Yamanoi, K., and Kawamura, K.: Evidence of formation of submicrometer water-soluble organic aerosols at a deciduous forest site in northern Japan in summer, J. Geophys. Res., 117, D19213, doi:10.1029/2012JD018250, 2012.

Mochizuki, T., Endo, Y., Matsunaga, S., Chang, J., Ge, Y., Huang, C., and Tani, A.: Factors affecting monoterpene emission from Chamaecyparis obtusa, Geochemical J., 45, 15-22, 2011.

Mochizuki, T., Miyazaki, Y., Ono, K., Wada, R., Takahashi, Y., Saigusa, N., Kawamura, K., and Tani, A.: Emissions of biogenic volatile organic compounds and subsequent formation of secondary organic aerosols in a Larix kaempferi forest, Atmos. Chem. Phys., 15, 12029-12041, doi:10.5194/acp-1512029-2015, 2015.

Pöhlker, C., Huffman, J. A., and Pöschl, U.: Autofluorescence of atmospheric bioaerosols - fluorescent biomolecules and potential interferences, Atmos. Meas. Tech., 5, 37-71, doi:10.5194/amt-537-2012, 2012.

Pöschl, U., Martin, S., Sinha, B., Chen, Q., Gunthe, S., Huffman, J., Borrmann, S., Farmer, D., Garland, R., and Helas, G.: Rainforest aerosols as biogenic nuclei of clouds and precipitation in the Amazon, Science, 329, 1513-1516, 2010.

Puxbaum, H. and Tenze-Kunit, M.: Size distribution and seasonal variation of atmospheric cellulose, Atmos. Environ., 37, 36933699, 2003.

Rogge, W. F., Medeiros, P. M., and Simoneit, B. R.: Organic marker compounds in surface soils of crop fields from the San Joaquin Valley fugitive dust characterization study, Atmos. Environ., 41, 8183-8204, 2007.

Simoneit, B. R., Schauer, J. J., Nolte, C., Oros, D. R., Elias, V. O., Fraser, M., Rogge, W., and Cass, G. R.: Levoglucosan, a tracer for cellulose in biomass burning and atmospheric particles, Atmos. Environ., 33, 173-182, 1999.

Simoneit, B. R., Elias, V. O., Kobayashi, M., Kawamura, K., Rushdi, A. I., Medeiros, P. M., Rogge, W. F., and Didyk, B. M.: Sugars dominant water-soluble organic compounds in soils and characterization as tracers in atmospheric particulate matter, Environ. Sci. Technol., 38, 5939-5949, 2004.

Sintermann, J. and Neftel, A.: Ideas and perspectives: on the emission of amines from terrestrial vegetation in the context of new 
atmospheric particle formation, Biogeosciences, 12, 3225-3240, doi:10.5194/bg-12-3225-2015, 2015.

Spracklen, D. V. and Heald, C. L.: The contribution of fungal spores and bacteria to regional and global aerosol number and ice nucleation immersion freezing rates, Atmos. Chem. Phys., 14, 90519059, 2014.

Xu, L., Guo, H., Boyd, C. M., Klein, M., Bougiatioti, A., Cerully, K. M., Hite, J. R., Isaacman-VanWertz, G., Kreisberg, N. M., Knote, C., Olson, K., Koss, A., Goldstein, A. H., Hering, S. V., de Gouw, J., Baumann, K., Lee, S.-H., Nenes, A., Weber, R. J., and Ng, N. L.: Effects of anthropogenic emissions on aerosol formation from isoprene and monoterpenes in the southeastern United States, P. Natl. Acad. Sci. USA, 112, 37-42, 2015.

Yttri, K. E., Aas, W., Bjerke, A., Cape, J. N., Cavalli, F., Ceburnis, D., Dye, C., Emblico, L., Facchini, M. C., Forster, C., Hanssen, J. E., Hansson, H. C., Jennings, S. G., Maenhaut, W., Putaud, J. P., and Tørseth, K.: Elemental and organic carbon in $\mathrm{PM}_{10}$ : a one year measurement campaign within the European Monitoring and Evaluation Programme EMEP, Atmos. Chem. Phys., 7, 5711-5725, doi:10.5194/acp-7-5711-2007, 2007.

Zhang, Q., Jimenez, J., Canagaratna, M., Allan, J., Coe, H., Ulbrich, I., Alfarra, M., Takami, A., Middlebrook, A., and Sun, Y.: Ubiquity and dominance of oxygenated species in organic aerosols in anthropogenically-influenced Northern Hemisphere midlatitudes, Geophys. Res. Lett., 34, L13801, doi:10.1029/2007GL029979, 2007.
Zhao, Y., Kreisberg, N. M., Worton, D. R., Isaacman, G., Gentner, D. R., Chan, A. W., Weber, R. J., Liu, S., Day, D. A., and Russell, L. M.: Sources of organic aerosol investigated using organic compounds as tracers measured during CalNex in Bakersfield, J. Geophys. Res., 118, 11388-11398, 2013.

Zhu, C., Kawamura, K., and Kunwar, B.: Organic tracers of primary biological aerosol particles at subtropical Okinawa Island in the western North Pacific Rim, J. Geophys. Res., 120, 5504-5523, 2015a.

Zhu, C., Kawamura, K., and Kunwar, B.: Effect of biomass burning over the western North Pacific Rim: wintertime maxima of anhydrosugars in ambient aerosols from Okinawa, Atmos. Chem. Phys., 15, 1959-1973, doi:10.5194/acp-15-1959-2015, 2015 b.

Zhu, C., Kawamura, K., and Fu, P.: Seasonal variations of biogenic secondary organic aerosol tracers in Cape Hedo, Okinawa, Atmos. Environ., 130, 113-119, 2016.

Ziemann, P. J. and Atkinson, R.: Kinetics, products, and mechanisms of secondary organic aerosol formation, Chem. Soc. Rev., 41, 6582-6605, 2012. 